Journal of Humanities and Social Sciences Studies (JHSSS)

ISSN: 2663-7197

DOI: 10.32996/jhsss

Journal homepage: www.al-kindipublisher.com/index.php/jhsss

\title{
Feminism in Pakistan and Emerging Perspectives
}

Marghoob Tarar ${ }^{1}$, Rana Hamza Arif ${ }^{2}$, Khawaja Abdul Rahman ${ }^{3}$, Khalid Husnain ${ }^{4}$, Muhammad Suleman $^{5}$, Aqasha Zahid ${ }^{6}$, Muhammad Umar Fida ${ }^{7}$, Khurram Ibrar ${ }^{8}$, Adil Shafiq ${ }^{9}$

${ }^{1}$ Government College University, Lahore

${ }^{2}$ Punjab Group of Colleges, Lahore

${ }^{3}$ Punjab Group of Colleges, Gujranwala

${ }^{4}$ Government Degree College Raiwind, Lahore

${ }^{5}$ Meridian Academy, Lahore

${ }^{6}$ Madarasa-tul-Binat, Lahore

${ }^{7}$ Lahore Islamic University/Markaz Bait ul Ateeq

${ }^{8}$ Punjab College, Raiwind Lahore

${ }^{9}$ Punjab Colleges Campus 11, Lahore

Corresponding Author: Marghoob Tarar, E-mail: taraarmarghoob7@gmail.com

\section{ARTICLE INFORMATION}

Received: October 02, 2020

Accepted: November 25, 2020

Volume: 2

Issue: 6

DOI: $10.32996 /$ jhsss.2020.2.6.25

\section{KEYWORDS}

Feminism, Pakistan, feminism

trends, feminism modes

\section{ABSTRACT}

Since March 2019, local NGOs in Pakistan are organizing "Aurat March" (Women March) in month of March to raise voice against indigenous feminine issues and violence against women. In hindu-originated society like Pakistan, where Islamic women rights haven't implemented in its true spirit yet, digesting such a "liberal" act is not easily digestible. Thus different intellectual classes took social media on fire to outdo each other and central topic of cross arguments was slogans raised in the March. Raising slogans is a traditional way of weaker class in society to demonstrate against discrimination and emit emotional suffocation. To study underlying meanings of much debated slogans of Aurat March in Pakistan, discourse analysis is employed which also facilitated to indicate emerging dimension socio-religious debates and opinions towards feminism in Pakistan.

\section{Introduction}

In March 2019, many Pakistani women associated with all social classes and professions came out in streets while holding slogans and placards. This march is labeled as "Aurat March" or "Women March". The march stirred a heated debate among all societal classes and intellectual groups. The main issue of debates was socio-religious status of the slogans in society which claimed itself to be religious or Islamic. In March 2020, about 8 NGOs organized the march of similar theme in Karachi which spread in major cities including Lahore, Karachi, Islamabad, etc. By the participants, it was maintained that women in Pakistan face multiple types of discrimination in every sphere of their lives. The resistance not necessarily led towards much change.

Rather articles and analyses on print media, debates about the Aurat March on online platforms and social media illustrated a variety of intellectual streams which cannot be divided into traditional categories of feminist and anti-feminism. Accompanied by slogans and memes, each group presented its thoughts in ironic or heated way. It seems that subject and cause of crucial importance is now given to the mob which is dealing with it in typical mob style. Discourse analysis of slogans and media discussions can lead towards uncovering the underlying meanings of slogans and contemporary social and street mindsets towards feminism and gender roles. Thus is very important to conduct discourse analysis of raised slogans and online media debates for identification of emerging trends and dimensions of feminism and attitudes towards it in contemporary Pakistani society in academic way.

K C AL-KINDI CENTER R D FOR RESEARCH AND $\mathbf{R} \mathbf{D}$ DEVELOPMENT Your gateway to world-class research
Published by Al-Kindi Center for Research and Development. Copyright (c) the author(s). This is an open access article under CC BY license (https://creativecommons.org/licenses/by/4.0/) 


\section{Research Methodology}

The word "slogan" is originated from Gaelic language's "sluagh-ghairm" means army-cry or war-cry (Sharp 1984). According to Aristotle, thoughts and demands are conveyed through lyric poetry and drama characters. However, in modern era people tend to demonstrate their thoughts in direct way through slogans. Slogans, the artistic impressions, are used to express complex and suffocated violent thoughts. The analysis of slogan or part of slogan involves process of interpretation (Burke 1974). In public discourse, slogan and sloganeer are equally important. Discourse analysis studies relationship between language (slogans) and social context associated with sloganeer i.e. ideologies and beliefs as Fairclough claimed that "discourse is the use of language seen as a form of social practice, and discourse analysis is analysis of how texts work within socio-cultural practice" (Fairclough 1995). To analyze slogans raised at Aurat March 2019 discourse analytical methodology is adapted. Firstly, all related slogans were collected and then divided into groups by keeping in view their thematic similarity. Secondly, the emergent groups were then given by suitable title for sake of identifying the existing intellectual streams. Finally, underlying meanings of slogans and discussions are figured out with help of interpretations led by media analysts.

\section{Heated Slogans of Aurat March 2019}

Slogans which are enlisted below caused trigging of heated debates on social media. While forming the inclusion criteria, slogans about women's biological issues (i.e. menstruation) and in which abusive language is used are excluded and only those are selected which are parallel to the march's manifesto:

\begin{tabular}{|c|}
\hline لو لو بيُّه كئي صحيح سح \\
\hline آج واقعى مان بهن ايك بو ربى بـ \\
\hline مان بون، بهن بون، كالى نبين بوب \\
\hline تمهار > باب كى سرّك نبيس به \\
\hline إنانـا كهانا خود كرم كرو \\
\hline مجهـ كيا معلوم تمهار ا موزه كهان بـ \\
\hline أكيلى ، آواره، آز اد \\
\hline 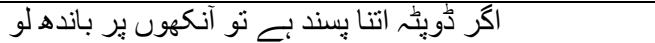 \\
\hline كى تسبيح روز بِّذهو \\
\hline شادى كل علاوه اور بهى بهت كام بين \\
\hline My body is not your battlefield \\
\hline Arrange marches not marriages \\
\hline مي مين نيبن تمهارى غيرت \\
\hline جبيز كى مانگ بـ غيرتى كا كام \\
\hline Women are not your punching bags \\
\hline Trnaswomen are women, shut up! \\
\hline ميرى بمت سع دُرو مت \\
\hline 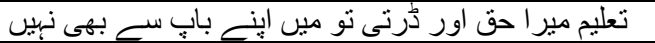 \\
\hline ا مير ا جسم ميرى مرضى \\
\hline I will build a house you can't kick me out from \\
\hline A woman's place is in the Kitchen, Resistance \\
\hline
\end{tabular}

\section{Slogans Raised by Men in the "Aurat March" Procession}

While some University students were holding bags with picture of Qandeel Baloach, others were holding the slogans which are as follow:

\begin{tabular}{|c|}
\hline $\begin{array}{l}\text { Its OK to be sensitive } \\
\text { مرد مت بنو، انسان بنو }\end{array}$ \\
\hline Smashing the patriarchy is my cardio \\
\hline I raised a feminist and I am proud of it \\
\hline كهانا كرم كرنا سيكه ليا؟ \\
\hline 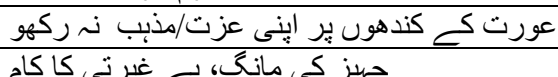 \\
\hline Let's talk about marital rape \\
\hline
\end{tabular}




\section{A. Emerged Dimensions in Women-led Debates}

\section{Reactions to Masculine Abuse and Oppression}

The manifesto of Aurat March mentioned following points as their agenda for organizing the event which is also interpreted through the slogans:

i. End to violence

ii. Economic justice

iii. Reproductive justice

iv. Women's political participation

v. Right to the city

\section{Demanding Balance between Household and Workplace}

According to a supporter, underlying meanings of the slogans must be understood. The slogans are not just about household tasks but it is about traditional masculine attitude of taking women services for granted by perceiving it as their moral imperative. There reported many incidents when women are murdered for not serving food in demanded way. Murder, mutilation, forced marriages, denial to basic rights, and objectification of women signifies that men perceive them as their property. So through the slogans like "mujhe kya pata tumhara muza kahan hai", and "khana garam karna seekh lia" etc working women actually demanded balance between household issues and workplace. (Aurat March and its discontents | Dialogue | thenews.com.pk n.d.)

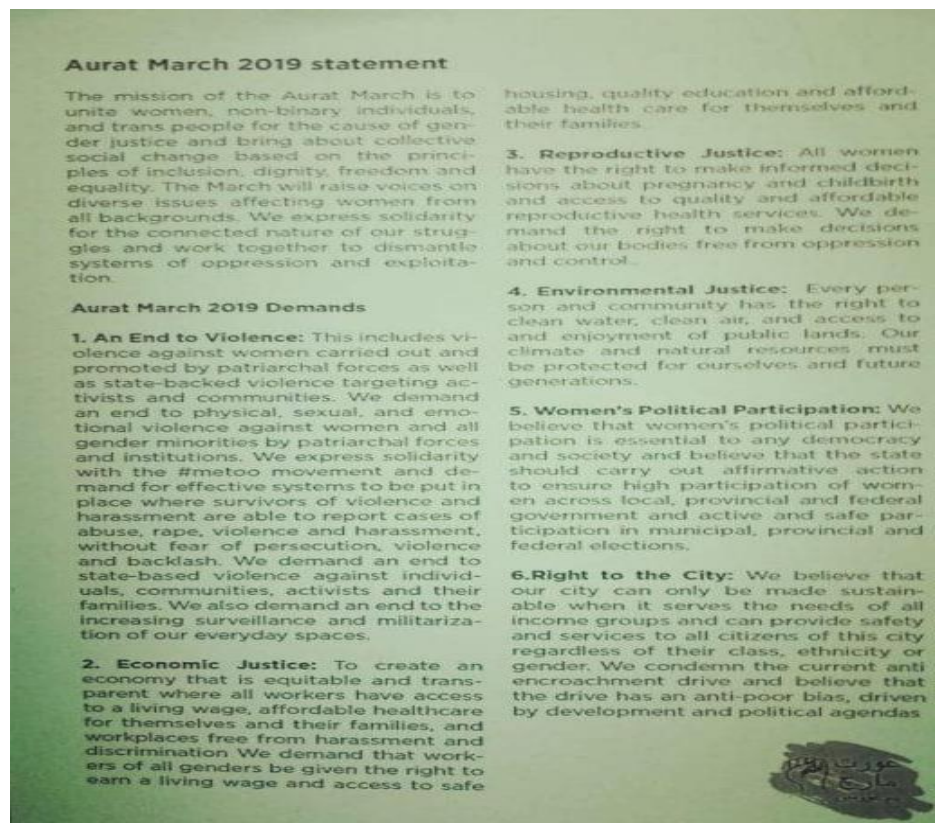

\section{Reclaiming the Commons rather Elites}

Besides the traditional debates of feminism and anti-feminism, there emerged a group which supports the Aurat march not because of its feminine nature but because of its mob approach. What Afifa Sheherbano said can be taken as a new emerging thought. She perceives the march as a chance for women belonging from all classes to raise their voice and disclose their problems. According to her, because of exclusion of public opinion, Women's day in Pakistan had become limited to NGO-led events and cake cutting ceremonies with government official in expensive hotels which are inaccessible to common women. But now demonstrations on streets depict that government has failed towards addressing women issues in Pakistan. This is among one of the reason why some officials and men offended by the march and raised slogans. (Propriety and protest I Encore | thenews.com.pk n.d.)

\section{Acceptance of Trans Community}

adhi na adhuri hoon, baraber aur puri hoon.

(Nor am I half neither incomplete, I am equal and complete)

Inclusion of transgender with slogans in the march represented diversity as thematic centrality of the rally. About the addition, a supporter said that it depicts the need to claim environmental justice, harassment free and discrimination free workplace atmosphere, equal rights to health care and bodies, and end to physical, emotional and sexual violence (The Aurat 
March challenges misogyny in our homes, workplaces and society, say organisers ahead of Women's Day - Art \& Culture Images n.d.). Social activist of trans community, Bindiya Rana emphasized on acceptance of all social groups including transgenders in all fields regardless of their "sexual orientation, class, ethnicity or religion" (Jabeen 2019).

\section{Social Appearance of the Movement: Real or Respected}

After being criticized by social groups and bearing opposite reactions from religious organizations two opposite opinions among feminists emerged. While some feminists thought that social acceptability is crucial for the success other take it as a passive approach which may lead towards the ultimate failure.

Analysis of contrast thoughts are as follow:

\begin{tabular}{|c|c|c|}
\hline Areas of Differences & Respected Feminism & Real Feminism \\
\hline Language of Slogans & Damaging and Judgmental & Each participant has right to voice \\
\hline Audience Opinion & Concerns of audience must be considered & $\begin{array}{l}\text { "Feminism with conditions is no } \\
\text { feminism" }\end{array}$ \\
\hline Fears & Fear of losing audience & Fear of losing powers \\
\hline Strategies & $\begin{array}{l}\text { Long term planning } \\
\text { Digestible strategies }\end{array}$ & $\begin{array}{l}\text { Tactical Strategies; where to show up } \\
\text { where to take calculative risks }\end{array}$ \\
\hline Approach towards Opponents & $\begin{array}{l}\text { Appeasing approach; reasonable and } \\
\text { respectable to the opponent i.e. patriarchy. }\end{array}$ & $\begin{array}{l}\text { Others would dictate what feminism } \\
\text { should and shouldn't be. }\end{array}$ \\
\hline Ethical Values & $\begin{array}{l}\text { Unthreatening to institutions of marriage and } \\
\text { family }\end{array}$ & $\begin{array}{l}\text { Read the manifesto and demands. } \\
\text { (Khatri 2019) }\end{array}$ \\
\hline
\end{tabular}

\section{6. "Religious" Reactions and Narratives against Aurat March}

Within women groups, there raised a class which strongly condemned the march by mentioning it anti-Islamic and anti-family system of Pakistan. For example in resolution number $157 \mathrm{Mrs}$ Nighat Orakzai submitted a dissenting note in KPK provincial assembly. Moreover, Tahir-ul-Qadri's organization, Minhaj-ul-Quran organized "Peace March" while opposing Aurat march. The relatable key points of these reactions are as follow:

1. The march was organized by some concealed powers with imported agendas;

2. From Islamic perspectives, demanded rights must be rejected;

3. Women who joined this march with shameful slogans are condemnable;

4. Events similar to this march are threat to Islamic ideology, and family system in Pakistan. (MWL International n.d.)

\section{Emerged Dimensions in Men-led Debates}

Anti-feminism is as historical as feminism. According to Zeina Toric Azad, contemporary patriarchal behaviors demonstrate variety of shades which should be identified by giving them a thematic title (Toric-Azad 2019); her findings are summarized as follow: 
The Safakeepers of Tradition

feminism resulted in 'negative changes' to saciety, traditional values of religion and family

Reaction to \#EndThePatriarchy

\section{The Evolution Egoists}

Feminism is Unnatural

because it challenges the

"wholesome" cultural idea of

womanhood

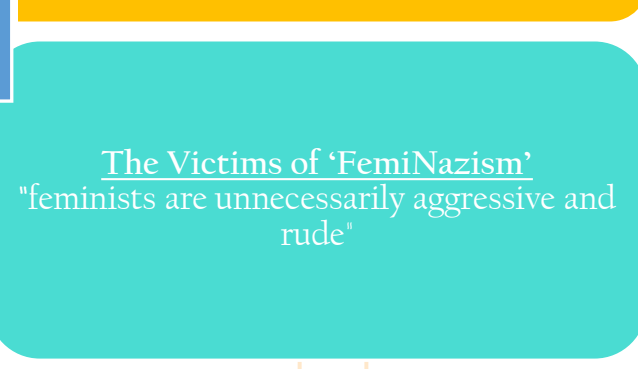

The Blissfully Ignorant Lot

"World has already achieved equality. And

anything further is unfair overkill."

Other emerged dimensions are as follow:

\section{Irony to Fragile Masculinities}

There emerged a group which adapted ironic tone to those men's "reservations" who overreacted to the slogans. The extracted lines from article of Muhammad Hanif can be taken as representative stream of thought of this group. ( دردانـ بدايت نامه برائح عورت مار م.d.)i

\section{Bashing the Slogans}

A group consisting media persons like Orya Maqbool Jaan, Aftab lqbal, Amir Liaqat etc. bashed the women who participated in the march because of their slogans. The statement of Orya Maqbool (عورت. جديد تهذيب كا بل بورد- اوريا مقبول جان 2019) can be taken as the representative one in which, according to him, two social aspects of Pakistani society were put on target:

i. Family System

ii. Feminine Shyness

(AamirLiaquat Aamir Liaquat Husain

It was a March against women in Pakistan, it was a March against about the real issues women face in Pakistan, itvwas a \#HateMarchyoutu.be/o7Cz8E3wnAU 


\section{Every Action has Reaction: "Threats" of Mard March}

Men in Karachi threat of organizing "Mard March" to compete with Aurat March. The march was organized on March 24, 2019 in Fair Hall Karachi in which boys held following slogans:

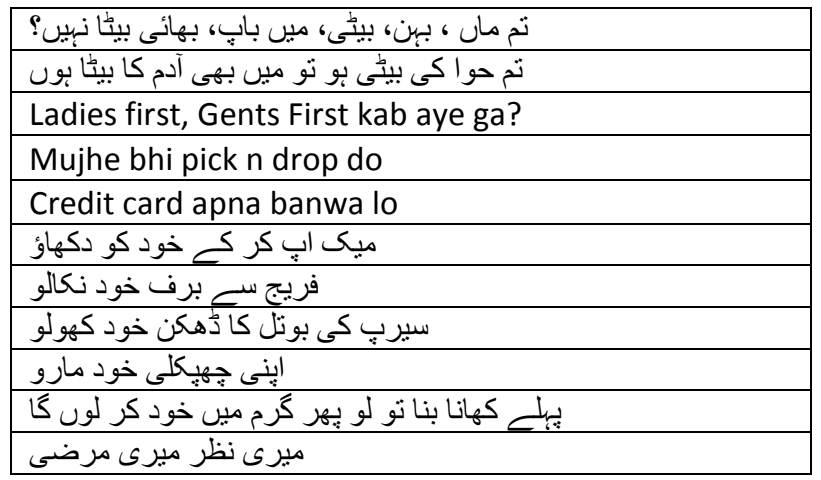

\section{Man and Woman-A Complete Team}

In all this intellectual chaos, another perspective came with the statement of the actor Ahmad Ali Butt who mentioned man and woman as a complete team:

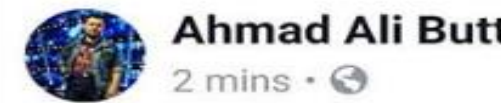

Its amazing to see some women hold a banner of "APNI ROTI KHUD BANAO" as if they make roties everyday in their homes... Babi Instagram ya snapchat say fursat millay ge tu maloon hoga na ke Roti kaysay pakte hay. Stop using \#feminism, as an excuse to Hate on Men or to increase your followers. true \#feminism is about men and women working as a team and sharing responsibilities let that be woman making a Roti while your man picks up Kids from school or man Putting kids to sleep while your wife has a job to do.

So lets make it clear that With a supporting woman a man is complete and with a supporting man a woman is Free. Thank you

\section{Men against Patriarchy, chauvinism and Misogyny}

Abdullah Mashud, a person on social media, put forward another perspective. He said that the whole event must not be delegitimized due to some slogans which received disproportionate amount of coverage. Plentiful placards demonstrated genuine demands which only a psychopath can disapprove but didn't get attention they merited. According to Mashud, the convenient saying "not all men" is actually harming the society. Taking responsibilities of fellow men's wrong doings wouldn't let our country to become a safer place for women. Rather taking responsibilities like that, doing a bit to set things right will convert our country where women will not feel the need to march. (Ala-ud-Din Academy 2019)

\section{Abusing Women Leaders of Aurat March}

Feminist movement took a shocking turn in February 2020 when heated debate between famous Pakistani drama writer Khalil-ur-Rehman Qamar and Woman activist Marvi Sarmad converted into an abusive one. After the incident, electronic media and social media took Rehman on fire. He was bashed and shamed by not only by pro-feminist groups but also by colleagues of media industry. On the other hand societal class holding patriarchal perspective praised Rehman and tried to 
prove Marvi as traitor, Indian agent and criticized her dresses, character etc. Unexpectedly, Rehman didn't show himself on the march day despite his claims to lead his own march for women who are, according to him, modest in character but women march was concluded in a non-voilant way. Sarmad-Rehman controversy revealed that intolerant patriarchal mindset of subcontinent still needs more time to witness women voicing against harms being done to themand tolerate debates for rights of women in Pakistan.

\section{Conclusion}

In modern era, academicians should study views and reviews in categorical way. The 'majority' opinion in combine form can provide shelter to such intellect which is hideous to the progressive society. Thematic divisions of the intellectual dimensions show that each opinion among men and women led debate are supported by some concerns and tactics which must be tackled carefully. To make feminism and woman rights' demands successful in Pakistan, all intellectual dimensions must be dissected and addressed rather disregarding them. Such approach will be more suitable to the modern feminism.

\section{References}

[1] Ala-ud-Din Academy. (2019). To Reflect and Act. Ala-ud-Din Academy. https://www.facebook.com/ALDAcademy/posts/to-reflectand-act/2159742534094165/.

[2] Aurat March and Its Discontents (2020). | Dialogue | Thenews.Com.Pk." https://www.thenews.com.pk/tns/detail/567460-auratmarch-discontents (August 29, 2020).

[3] Burke, K. (1974). The Philosophy of Literary Form. Univ of California Press.

[4] Fairclough, N. (1995). Critical discourse analysis: The critical study of language. Routledge.

[5] International, M. (2020). MWL Holds a Peaceful March to Decry Anti-Women Agenda - Minhaj-UI-Quran." https://www.minhaj.org/english/tid/46325/MWL-holds-a-peaceful-march-to-decry-anti-women-agenda.html (August 29, 2020).

[6] Jabeen, Y. (2019). Everything You Need to Know about Aurat March. cutacut. https://cutacut.com/2019/03/06/everything-you-needto-know-about-aurat-march/ (August 29, 2020).

[7] Khatri, S. (2019). Should Feminists Claim Aurat March's 'Vulgar' Posters? Yes, Absolutely. DAWN.COM. https://www.dawn.com/news/1469815 (August 29, 2020).

[8] Propriety and Protest (2020). | Encore | Thenews.Com.Pk." https://www.thenews.com.pk/tns/detail/567418-propriety-protest

[9] Sharp, S. (1984). Advertising Slogans of America. Scarecrow Pr.

[10] “The Aurat March Challenges Misogyny in Our Homes, Workplaces and Society, Say Organisers Ahead of Women's Day - Art \& Culture - Images." https://images.dawn.com/news/1181993 (August 29, 2020).

[11] Toric-Azad, Z. (2019). The Many Faces of Anti-Feminism in Pakistan. Images. https://images.dawn.com/news/1182422 (August 29, 2020).

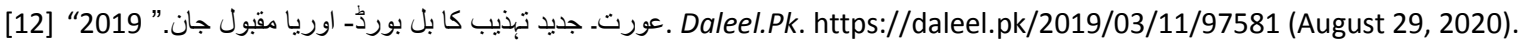

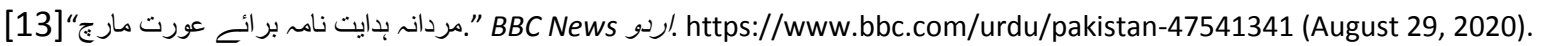




\section{Endnotes}

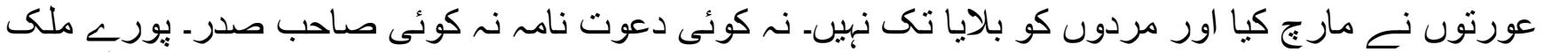

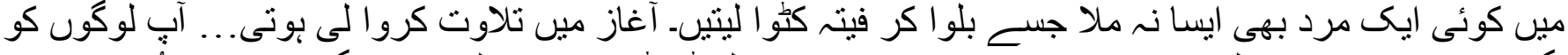

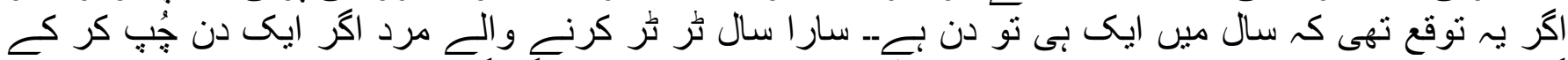

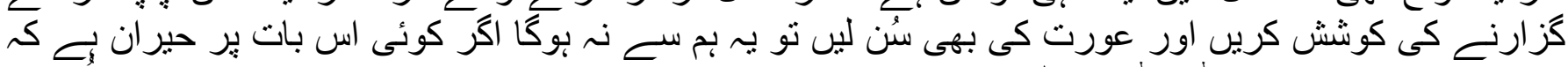

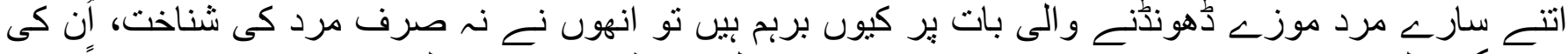

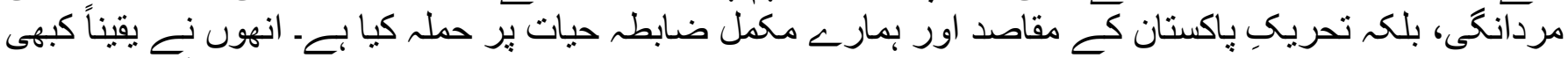

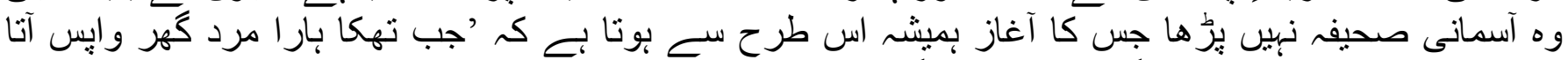

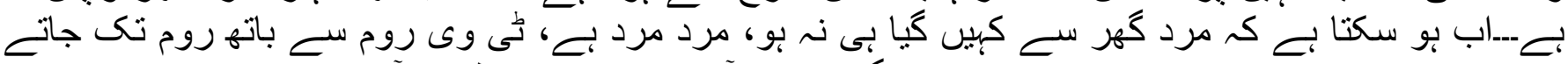

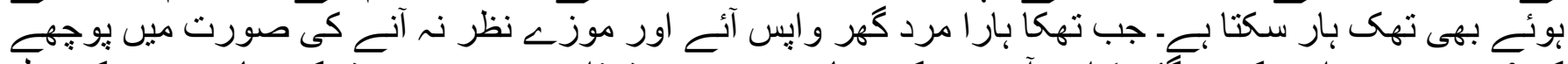

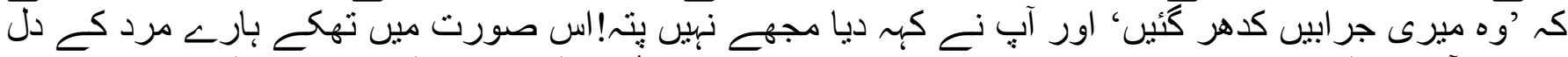

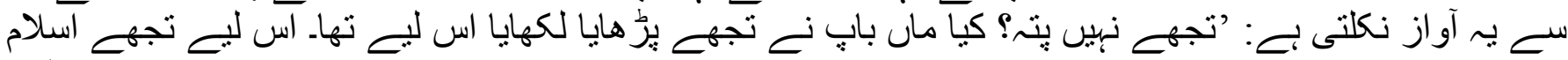

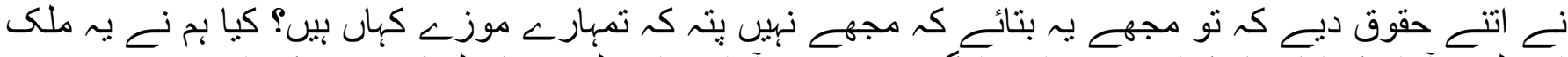

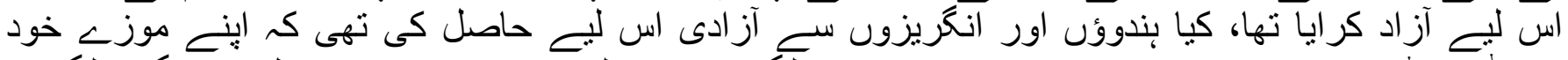

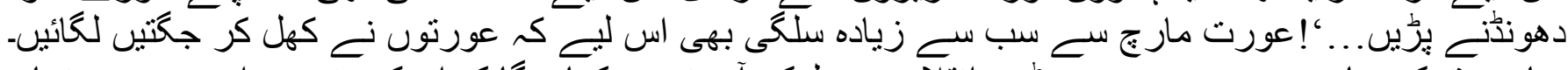

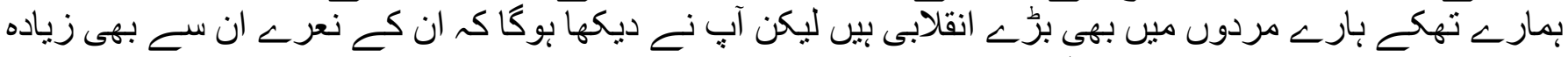

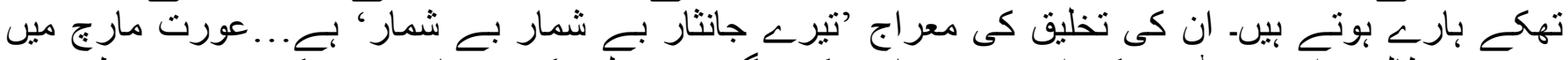

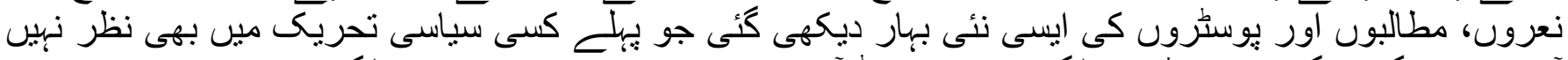

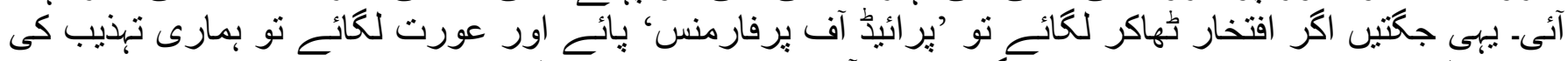

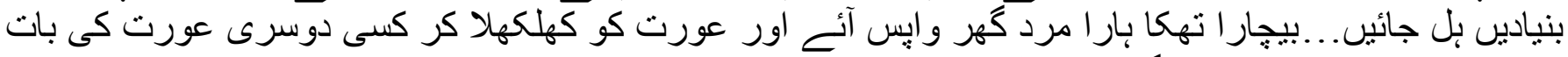

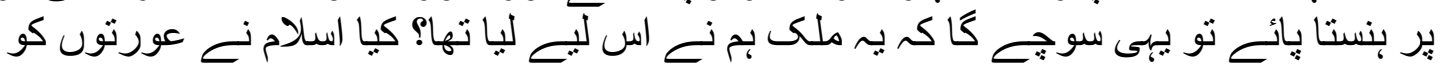

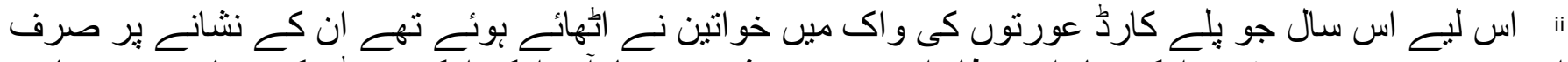

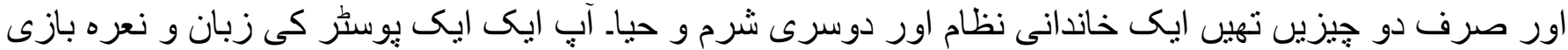

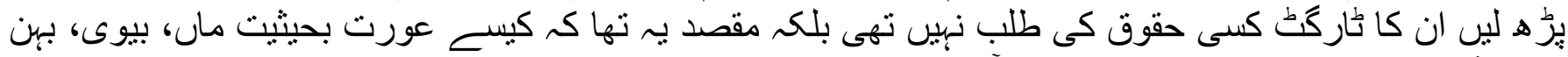

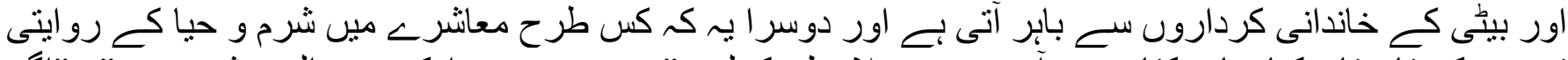

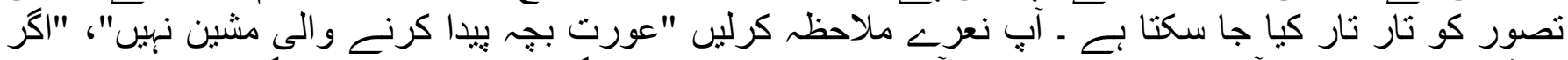

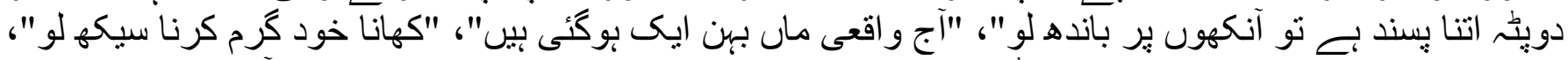

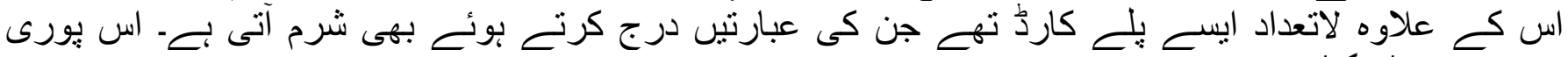

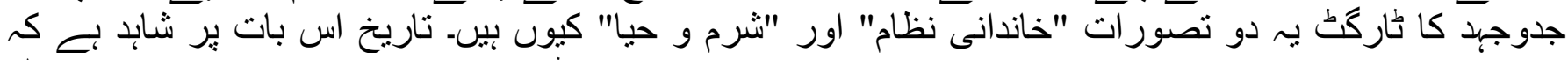

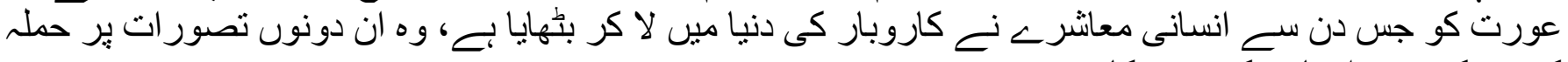
كرنخ كـ بعد ايسا مدكن بو سكان. 